\author{
M.Zh. Burkeyev, G.K. Kudaibergen, Ye.M. Tazhbayev, \\ G.K. Burkeyeva, A.V. Omasheva, N.A. Yesentayeva, A.N. Bolatbay \\ Ye.A. Buketov Karaganda State University, Kazakhstan \\ (E-mail: gulshahar90@mail.ru)
}

\title{
The number average and mass average molar masses of polyethylene(propylene)glycol fumarates
}

\begin{abstract}
Unsaturated polyesters are interesting for theoretical and practical studies, since along with the simplicity of economical production, contain in their composition unsaturated double bonds, which makes it possible to obtain spatially crosslinked structures on their basis. In this work polyethylene glycol fumarate, polypropylene glycol fumarate were synthesized by the step-growth polymerization of ethylene(propylene)glycol and fumaric acid. The compositions of polyethylene(propylene)glycol fumarates were determined using elemental analysis and IR spectroscopy. Some physicochemical characteristics of synthesized polyethylene(propylene)glycol fumarates were established. In order to state the correlation between the molar masses of polyethylene(propylene)glycol fumarates, the number average and mass average molar masses were found. As follows from the results presented in this paper mass average molecular masses of polyethylene glycol fumarate and polypropylene glycol fumarate calculated by the light scattering were around 2500 and 1488 a.e.m., the number average molar masses determined by the method of end groups were 2010 and 1245 a.e.m., respectively. It is shown that the methods of light scattering and end-group assay give good convergence and have a high degree of correlation. As a result of the study the correctness the light scattering method for the estimation of molecular masses of polyethylene(propylene)glycol fumarates was shown.
\end{abstract}

Keywords: unsaturated polyester resins, polyethylene glycol fumarate, polypropylene glycol fumarate, the number average molar mass, mass average molar mass, light scattering, titration, step-growth polymerization.

\section{Introduction}

The molar mass, which is one of the main characteristics of any chemical substance, plays a special role in case of high-molecular compounds, since it serves as a measure of length of the chain molecule. The latter is also characterized by the number of repeating units or the degree of polymerization of macromolecule. It should be noted that the molar mass of the polymer is the average statistical value, which refers to the molar masses of the macromolecules constituting the polymer. Polymers, unlike low-molecular substances, are polydisperse; they dissolve via preliminary swelling and in rare cases form colloidal solutions. A very large molar mass is typical for polymeric compounds and itoften changes from 8-10 thousand to several millions. Determination of the molecular mass of polymers is possible by using the classical methods (osmometry, ebullioscopy, cryoscopy, viscosimetry, etc.) and modern methods of investigation such as gel permeation chromatography, nephelometry, etc. Knowing the molar mass of the polymer necessary information on its structural features and properties can be obtained; also it is possible to carry out directed synthesis of substances based on properties.

Unsaturated polyesters due to the simplicity of economical production, availability of raw materials attract the attention of researchers, practitioners and have found wide practical use. The main and unique feature of unsaturated polyesters is the ability to copolymerize with various monomers to form valuable products that have special physicochemical and mechanical properties; they are characterized by low toxicity and relative availability. As the literature analysis shows, only co-monomers of hydrophobic nature are involved in the copolymerization with unsaturated polyesters [1-3] and synthesized polymeric materials can be use construction products. The problems of copolymerization of unsaturated polyesters with hydrophilic ionic monomers remain relevant until recently. It opens up prospects for the synthesis of new so-called «intelligent» polymers capable of reversibly reacting in response to insignificant changes in the environment. An important factor affecting the properties of synthesized copolymers is the molar masses of the initial unsaturated polyester resins. In literature there are contradictory data on the values of molar masses of unsaturated polyester resins. In this regard, it seemed interesting to compare the molar masses obtained by different methods.

With the aim of evaluation of the molar masses of synthesized polyethylene(propylene)glycol fumarate (p-EGF, p-PGF), this study presents the results on the determination of the number average and mass average molar masses obtained using light scattering method and end-group assay. 


\section{Method}

Polyethylene(propylene)glycol fumarates were obtained by step-growth polymerization of ethylene (propylene)glycol and fumaric acid of the ratio $1.05: 1 \mathrm{~mol}$ by heating and stirring them in a nitrogen medium [4]. After the reaction mixture reaches a temperature of $153^{\circ} \mathrm{C}$, a catalyst $\left(\mathrm{AlCl}_{3}\right)$ is introduced into it at an amount of $0,2 \%$ on total mass of the original monomer mixture. Stirring was continued for 6-8 hours until water was completely removed; after which the reaction mixture was cooled to room temperature. The route of the reaction was monitored by determining the acid number. The resulting resin was purified from the starting monomers by washing with acetone.

The number average molar mass of unsaturated polyesters was determined by acid number (AN) and hydroxyl number $(\mathrm{HN})$ by direct titration with $0.1 \mathrm{~N}$ and $0.5 \mathrm{~N} \mathrm{KOH}$ where phenolphthalein is used as an indicator.

$$
\begin{gathered}
M_{n}=\frac{56.11 \cdot 2 \cdot 1000}{A N+H N} ; \\
A N=\frac{\left(V_{1}-V_{2}\right) \cdot f \cdot 0.00561 \cdot 1000}{g},
\end{gathered}
$$

where $V_{1}$ and $V_{2}$ - the volume of $0.1 \mathrm{~N} \mathrm{KOH}$, consumed for the titration of sample with a polymer and a control sample, $\mathrm{ml}$.

$$
H N=\frac{\left(V_{1}-V_{2}\right) \cdot f \cdot 0.028 \cdot 1000}{g},
$$

where $V_{1}$ and $V_{2}$ - the volume of $0.5 \mathrm{~N} \mathrm{KOH}$, consumed for the titration of sample with a polymer and a control sample, $\mathrm{ml}$.

The Debye method (light scattering) was used to estimate the mass average molar mass [5]. Determination of the turbidity of polymer solutions was carried out by light scattering using a 2100 AN nephelometer from $\mathrm{HACH}$ at $\lambda=5460 \AA$.

The degree of scattering of monochromatic light by a solution (turbidity) $\tau^{0}$ is related to the osmotic pressure of the true solution by the following relation, known as the Debye equation:

$$
\tau^{0}=\frac{32(3.14)^{3} n_{0}^{2}\left(n-n_{0}\right)^{2}}{3 \lambda^{4} N_{A} C\left[\frac{\partial\left(\frac{\pi_{0}}{R T}\right)}{\partial C}\right]},
$$

where $n$ and $n_{0}$ - the refractive indexes of the solvent and solution, respectively; $N_{A}$ - Avogadro constant, $\mathrm{mol}^{-1} ; \pi_{0}$ - osmotic pressure, atm; $C$ - concentration of solution, $\mathrm{g} / \mathrm{cm}^{3} ; \lambda$ - wavelength, $\mathrm{nm}$.

The accuracy of determining the molar mass and conformational features of molecules depends on the nephelometric features of the solvent used [5].

It was noted above that the osmotic pressure is a characteristic of the change in chemical potential of the solution and is due to the activity of the dissolved substance $a^{0}$. It can be shown that the turbidity of the system increases with the increasing the activity of dissolved particles. In another words, with increasing $a^{0}$, the proportion of scattered light increases. The intensity of the scattered light $I_{0}$ observed at an angle $\theta$ to the incident monochromatic ray is called the optical anisotropy of the dissolved polymer particles and varies with the angle of observation. The optical anisotropy of these particles is that the intensity of the scattering is not the same along the different axes of the molecular coil. The dependence of the intensity of the scattered light on the angle of observation of the scattered ray is called the Rayleigh ratio (number), or the reduced intensity.

$$
R_{\theta i}=r^{2} I_{\theta i} / I_{0},
$$

where $I_{\theta i}$ and $I_{0}$ - the intensity of scattered and incident light, respectively; $r$ - distance from particle to observer.

In practice, when determining the turbidity often a value $R_{\theta i}$ is calculated, but not $\tau^{0}$. Therefore:

$$
\frac{H C}{R_{\theta i}}=\frac{1}{\bar{M}_{w}}+\frac{2 B C}{R T} .
$$


At small values of $C$, the dependence $H C / R_{\theta i}=f(C)$ is expressed by a straight line that cuts off $C \rightarrow 0$ on the $y$-axis is a segment equal to the reciprocal of the molar mass.

$$
\left[\frac{H C}{R_{\theta i}}\right]_{c \rightarrow 0}=\frac{1}{\bar{M}_{i}} \text {. }
$$

The concentration of the initial solution for the determination of the polymer at the wavelength region $10^{5}-10^{7} \mathrm{~nm}$ is of the order of $2 \cdot 10^{-3} \mathrm{~g} / \mathrm{ml}(0.2 \mathrm{~g} / \mathrm{l})$. For this, a sample of unsaturated polyester of $0.1 \mathrm{~g}$ (accurate to 0.0001$)$ was placed in a pre-weighed volumetric flask $(\sim 50 \mathrm{ml})$ with a clogged cork. Further it was dissolved in an increasing volume of a thoroughly purified and repeatedly distilled solvent, then brought to a mark and weighed. The concentration of the solution $C_{1}\left(\mathrm{~g} / \mathrm{cm}^{3}\right)$ was calculated using the formula

$$
C_{1}=m_{p} \rho / m_{s}
$$

where $m_{p}$ - polymer mass, $\mathrm{g} ; \rho-$ density of solvent, $\mathrm{g} / \mathrm{cm}^{3} ; m_{s}$ - mass of solvent, $\mathrm{g}$.

Then, $30 \mathrm{ml}$ of the prepared solution was transferred to a cuvette of the instrument; the turbidity of the solution and the refractive indexes were determined until complete reproducibility.

A series of solutions were prepared from the available solution by successively diluting an aliquot $(\sim 30 \mathrm{ml})$ of each previous solution to $50 \mathrm{ml}$ in a volumetric flask, then turbidity and refractive indexes were measured. The concentration of the subsequent solutions was calculated according to the above formula. Based on the calculated values, a plot of the dependence $H C / R_{\theta i}-f(C)$. Extrapolating the resulting straight line to $C=0$, we obtained a segment that corresponds to the limiting value $H C / R_{\theta i}=1 / \bar{M}_{w}$.

\section{Results and Discussion}

Polyethylene(propylene)glycol fumarates were obtained by step-growth polymerization of fumaric acid and ethylene glycol according to the following scheme [4]:<smiles>O=C(O)C=CC(=O)O</smiles><smiles>[R]CCCCOC(=O)C=CC(=O)OCC([R])C</smiles>

Polyethylene(propylene)glycol fumarates were identified by IR spectroscopy (Fig. 1). In the IR spectra of synthesized polyethylene(propylene)glycol fumarates, the absorption bands at $755 \mathrm{~cm}^{-1}$ due to pendulum oscillations of $-\mathrm{CH}_{2}-$ bonds are observed, and absorption bands at $1162 \mathrm{~cm}^{-1}$ region confirm the presence of the $-\mathrm{C}-\mathrm{O}-\mathrm{C}-$ bond of the ester. The intense absorption band at $1461 \mathrm{~cm}^{-1}$ indicates the vibrations of $-\mathrm{C}-\mathrm{H}$ bonds. The presence of $-\mathrm{C}=\mathrm{O}$ bond and symmetrically located $-\mathrm{CH}$ bonds in the $\mathrm{CH}_{2}$ and $\mathrm{CH}_{3}$ groups are characterized by absorption bands at $1736 \mathrm{~cm}^{-1}$ and $2985 \mathrm{~cm}^{-1}$, respectively. The spectra exhibit an intense peak at $1306 \mathrm{~cm}^{-1}$ reflecting the presence of the $-\mathrm{C}=\mathrm{C}$-group of the polyester. The presence of $\mathrm{p}$-EGF and $\mathrm{p}-\mathrm{PGF}-\mathrm{C}=\mathrm{C}-$ bonds in the structure indicates the formation of an unsaturated polyester.

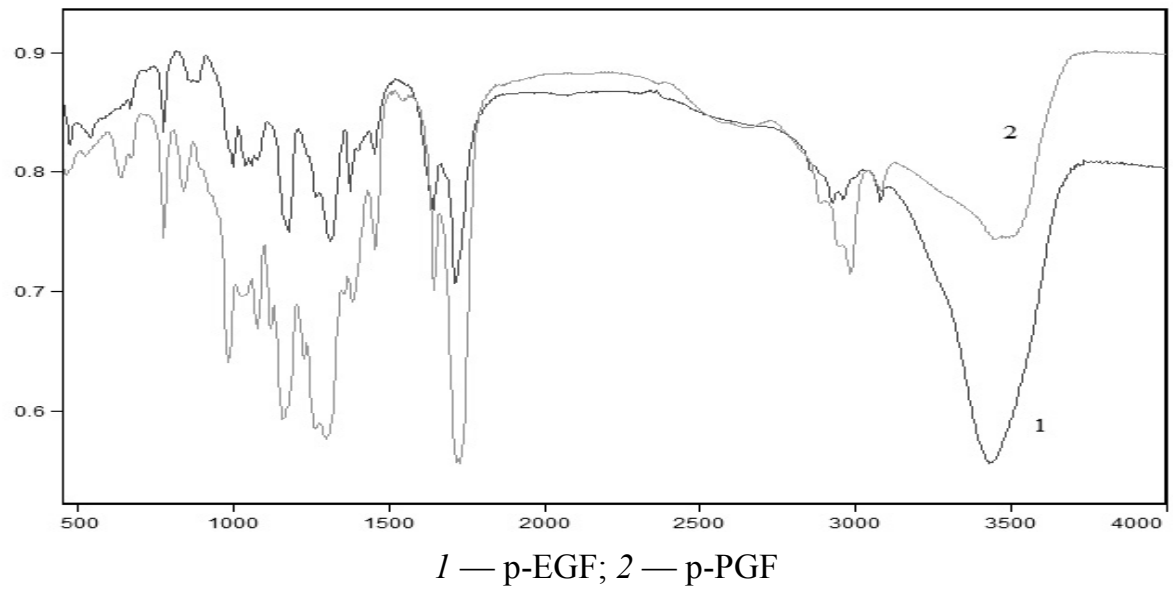

Figure 1. IR spectra 
The light scattering method is the most reliable and convenient out of the few absolute methods for the determination of the mass average molar masses of polymers, covering an exceptionally wide range of molecular masses. In addition, it is a direct method for measuring the size of macromolecules in solution, used for approbation and calibration of other, indirect methods (in particular, hydrodynamic methods).

The results of metrological processing of straight lines and calculated values of molar mass are given in Table. The data obtained were confirmed by a mathematical study and a graph of the accuracy of the coordinate $H C / R_{\theta i}-f(C)$ (Figs. 2, 3). Extrapolation of the $H C / R_{\theta i}$ dependence on $C$ is determined by the formula extrapolated to the zero scattering angle $\theta$ in accordance with equation.

Thus, the molar mass of the polymer is calculated and determined by the intersection values. As follows from the results presented in Table, polyethylene glycol fumarate and polypropylene glycol fumarate have molar masses of the order of 2500 and 1488, respectively, and the values of the molar masses studied in the three units of turbidity are in good agreement. The values of $\bar{M}_{w}$ listed in Table are in good accordance with the data calculated from the titration [3].

$\mathrm{T}$ a b l e

Molar mass features of an unsaturated polyester resin

\begin{tabular}{|c|c|c|c|c|c|}
\hline Object & $H \times 10^{-5}$ & $\left(\frac{H C}{R_{\theta i}}\right)_{c \rightarrow 0}=\frac{1}{\bar{M}_{w}} \times 10^{-3}$ & $\bar{M}_{w}$ & $\bar{M}_{n}$ & $D_{m}$ \\
\hline p-EGF & 6.401 & 0.400 & 2500.00 & 2010.59 & 1.24 \\
\hline p-PGF & 3.3010 & 0.6720 & 1488.00 & 1245.34 & 1.19 \\
\hline
\end{tabular}

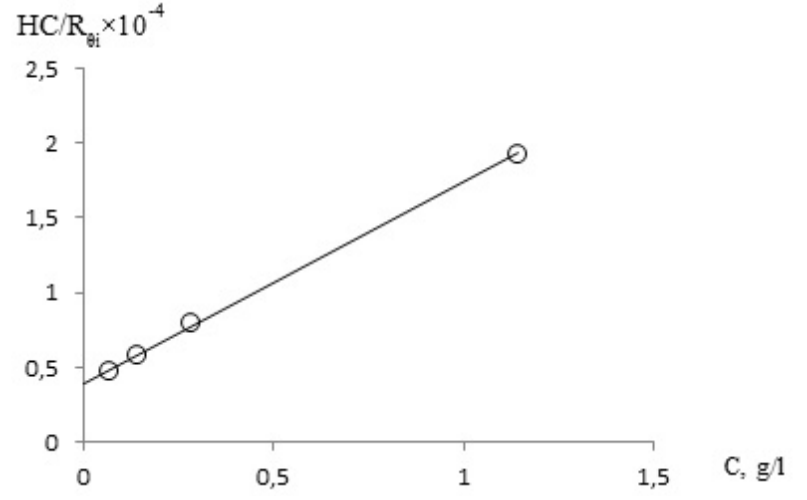

Figure 2. Dependence of $H C / R_{\theta i}$ on the concentration $(C)$ for solutions of $\mathrm{p}$-EGF in chloroform

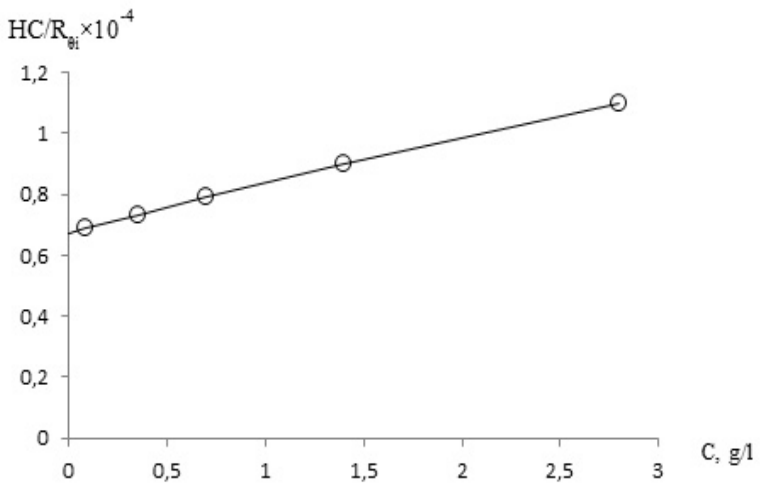

Figure 3. Dependence of $H C / R_{\theta i}$ on the concentration $(C)$ for solutions of $\mathrm{p}$-EGF in chloroform

In the literature, it is noted that the light scattering method is most applicable for polymers with a high molar mass (above 10,000). To confirm the correctness of the use of the light scattering method for the estimation of the molar masses of polyethylene(propylene)glycol fumarates, we additionally determined the numberaverage molar mass by the method of determining the end groups. This method is most effective forlinear condensation polymers of which the molar mass is usually below 20,000.

\section{Conclusions}

The set of experimental results on the establishment of the mass-average and number-average molar masses obtained by light-scattering and the determination of end groups have similar values, indicating the oligomeric nature of p-EGF and p-PGF. Thus, as a result of the study, the correctness of the light scattering method for the estimation of molecular masses of polyethylene(propylene)glycol fumarate were shown.

\section{References}

1 Бениг Г.В. Ненасыщенные полиэфиры: строение и свойства / Г.В. Бениг. — М.: Химия, 1968. — 253 с.

2 Седов Л.Н. Модифицирование химической структуры полималеинатов и полифумаратов для регулирования свойств сополимеров на их основе / Л.Н. Седов, Г.М. Авдеева, Е.Г. Зильберман, Н.Ф. Пугачевская, О.И. Савичева // Вестн. техн. и эконом. информации. - 1970. — № 2. - С. 16. 
3 Анисимов Ю.Н. Привитая сополимеризация винилацетата с ненасыщенной олигоэфирной смолой и характеристики отвержденных композиций / Ю.Н. Анисимов, Н.А. Вонсович, О.Б. Грехова // ЖПХ. — 1996. — Т. 69, № 2. — С. $312-316$.

4 Патент № 31052. Казахстан. Способ получения ненасыщенных полиэфирных смол на основе пропиленгликоля, фталевого ангидрида и фумаровой кислоты / М.Ж. Буркеев, Е.М. Тажбаев и др. Опубл. 16.03.2016.

5 Козлов Н.А. Физика полимеров / Н.А. Козлов, А.Д. Митрофанов. — Владимир: ВлГУ, 2001. — 345 с.

М.Ж. Бүркеев, Г.Қ. Кұдайберген, Е.М. Тажбаев, Г.К. Бүркеева, А.В. Омашева, Н.А. Есентаева, А.Н. Болатбай

\title{
Полиэтилен(пропилен)гликольфумараттардың ортасандық және ортамассалық молекулярлық массалары
}

Қанықпаған полиэифрлі шайырлар теориялық және практикалық жағынан қызықты болып табылады, себебі алудың қарапайымдылығы мен экономикалық тиімділігіне қарамастан, құрамында қос байланыстың болуынан олардың негізінде кеңістікті-тігілген құрылымды қосылыстарды алуға мүмкіндік береді. Мақалада этилен(пропилен)гликоль мен фумаратты поликонденсациялау реакциялары арқылы полиэтиленгликольфумарат, полипропиленгликольфумарат синтезделінді. Полиэтилен(пропилен)гликольфумараттардың құрамы элементтік талдау, ИҚ-спектроскопия көмегімен анықталды. Синтезделген полиэтилен(пропилен)гликольфумараттардың кейбір физика-химиялық сипаттамалары белгілі болды. Полиэтилен(пропилен)гликольфумараттардың молекулалық массалары арасындағы арақатынастылық дәрежесін анықтау мақсатында ортасандық және ортамассалық молекулалық массалары табылды. Авторлар көрсеткен мәліметтерден полиэтиленгликольфумарат және полипропиленгликольфумарат жарық шашырату әдісі бойынша ортамассалық молекулалық массалары 2500 пен 1488 а.е.м., ал шеткі топтардың мөлшерін анықтау әдісі бойынша ортасандық молекулалық массалары сәйкесінше 2010 а.е.м. және 1245 а.е.м. тең екені көрсетілді. Сонымен қатар жарық шашырату мен шеткі топтардың үлесін анықтау әдістерінің мәндері жақсы сәйкестік және жоғары арақатынастылық дәрежесіне ие. Жүргізілген зерттеулер нәтижесінде полиэтилен(пропилен)гликольфумараттардың молекулалық массасын анықтау кезінде жарық шашырату әдісінің қолданылуының дұрыстылығы дәлелденді.

Кілт сөздер: қанықпаған полиэфирлі шайырлар, полиэтиленгликольфумарат, полипропиленгликольфумарат, ортасандық молекулалық масса, ортамассалық молекулалық масса, жарық шашырату, титрлеу, поликонденсация.

М.Ж. Буркеев, Г.К. Кудайберген, Е.М. Тажбаев, Г.К. Буркеева, А.В. Омашева, Н.А. Есентаева, А.Н. Болатбай

\section{Среднечисловая и среднемассовая молекулярные массы полиэтилен(пропилен)гликольфумаратов}

\begin{abstract}
Ненасыщенные полиэфиры интересны для теоретических и практических исследований, поскольку, наряду с простотой, экономичностью получения, содержат в своем составе ненасыщенные двойные связи, что делает возможным получение на их основе пространственно-сшитых структур. В статье показано, что реакцией поликонденсации этилен(пропилен)гликоля и фумаровой кислоты синтезированы полиэтиленгликольфумарат и полипропиленгликольфумарат. Составы полиэтилен(пропилен)гликольфумаратов были установлены по данным элементного анализа, ИК-спектроскопии Определены некоторые физико-химические характеристики синтезированных полиэтилен(пропилен)гликольфумаратов. С целью определения корреляции между значениями молекулярных масс полиэтилен(пропилен)гликольфумаратов найдены среднечисловые и среднемассовые значения последних. Как следует из представленных в данной работе результатов, полиэтиленгликольфумарат и полипропиленгликольфумарат имеют среднемассовую молекулярную массу, рассчитанную методом светорассеяния, порядка 2500 и 1488 а.е.м. соответственно, среднечисловая молекулярная масса по методу определения доли концевых групп составляет 2010 и 1245 а.е.м. соответственно. Показано, что методы светорассеяния и определения концевых групп дают хорошую сходимость и имеют высокую степень корреляции. В результате проведенных исследований показана корректность применения метода светорассеяния для оценки молекулярной массы полиэтилен(пропилен)гликольфумаратов.
\end{abstract}

Ключевые слова: ненасыщенные полиэфирные смолы, полиэтиленгликольфумарат, полипропиленгликольфумарат, среднечисловая молекулярная масса, среднемассовая молекулярная масса, светорассеяние, титрование, поликонденсация. 


\section{References}

1 Benig, G.V. (1968). Nenasyshchennye poliefiry: stroenie i svoistva [Unsaturated polyesters: structure and properties]. Moscow: Khimiia [in Russian].

2 Sedov, L.N., Avdeyeva, G.M., Zilberman, Ye.G., Pugachevskaya, N.F., \& Savicheva, O.I. (1970). Modifitsirovanie khimicheskoi struktury polimaleinatov i polifumaratov dlia rehulirovaniia svoistv sopolimerov na ikh osnove 「Modification of the chemical structure of polymaleinates and polyfumarates to regulate the properties of copolymers based on them]. Vestnik tekhnicheskoi i ekonomicheskoi informatsii - Technical and Economic Information Bulletin, 2, 16 [in Russian].

3 Anisimov, Yu.N., Vonsovich, N.A., \& Grekhova, O.B. (1996). Privitaia sopolimerizatsiia vinilatsetata s nenasyshchennoi olihoefirnoi smoloi i kharakteristiki otverzhdennykh kompozitsii [Graft copolymerization of vinyl acetate with an unsaturated polyester resin and characteristics of cured compositions]. Zhurnal prikladnoi khimii - Journal of Applied Chemistry, 69, 2, 312-316 [in Russian].

4 Burkeyev, M.Zh., \& Tazhbayev, Ye.M., et al. (16.03.2016). Patent No. 31052 Kazakhstan. Sposob polucheniia nenasyshchennykh poliefirnykh smol na osnove propilenhlikolia, ftalevoho anhidrida i fumarovoi kisloty [Method for the preparation of unsaturated polyester resins based on propylene glycol, phthalic anhydride and fumaric acid] [in Russian].

5 Kozlov, N.A., \& Mitrafanov, A.D. (2001). Fizika polimerov [Physics of Polymers]. Vladimir: V1GU [in Russian]. 